\title{
Change in the Compressive Strength of Low and High Copper Amalgams in Relation to Time
}

\author{
Hiroyuki NAKAI*, Kazuomi SUZUKI*, Masao IRIE*, Koichi ARAI** \\ and Hirokazu HASHIMOTO** \\ * Department of Dental Materials, Okayama University Dental School, Okayama 700, Japan \\ ** Department of Dental Materials, Josai Dental University Sakado, Saitama 350-02, Japan
}

Received on February 27, 1984

Compressive strength was determined in various commercially available low and high copper amalgams periodically from 1 hour to 30 days and compared to the hardness reported previously. Characteristics of amalgam alloys during hardening are described.

Key Words: Compressive Strength, Low and High Copper Amalgams, Hardening Characteristics

\section{INTRODUCTION}

Amalgam alloys, having distinctive physical properties, are commercially available in this country, ${ }^{1)}$ with those having a high copper content and spherical particles being widely used.

It is a well known, that the hardening of an amalgam occurs very slowly, and 6 to 8 hours is necessary for reaching an acceptable strength (e.g., $80 \%$ of its 24 hou1-strength). From such reasons, finishing of restored amalgam should be made at least 24 hours after condensation.

Recently, fast hardening alloys are becoming widely used ${ }^{1-3)}$, indicating the demands of clinical practitioners. In this study, the hardening of amalgams were observed with compressive strength, determined periodically, and compared to those of determined with hardness, reported previously. $\left.{ }^{4}\right)$

\section{MATERIALS AND METHODS}

Seventeen alloys, 8 low and 9 high copper, were examined (Table 1). Specimens were prepared according to the A.D.A. Specification No. $1 .^{5-6)}$ Mixing of alloy with mercury was made with a mechanical amalgamator following the manufacturer's direction. These procedures are shown in Table 2. Five specimens were prepared for each experiments. Immediately after preparation, specimens were placed in an air conditioning oven, maintained at $37^{\circ} \mathrm{C}$.

Compressive strength was determined with a universal testing machine ${ }^{\#}$, a cross head speed of $2.0 \mathrm{~mm} / \mathrm{min}$ was applied. Determination was made periodically from 1 hour to 30 days after mixing.

\# Type RS-2, Shimadzu Seisakusho Co., Japan 
Table 1 Amalgam alloys applied

\begin{tabular}{|c|c|c|c|c|}
\hline Amalgam alloy & & Manufacturer & $\begin{array}{l}\text { Type of } \\
\text { commercial } \\
\text { products }\end{array}$ & Batch No. \\
\hline $\begin{array}{l}\text { Conventional } \\
\text { lathe-cut }\end{array}$ & $\begin{array}{l}\text { Luna } 2 \\
\text { Optaloy } \\
\text { Fluor Alloy* }\end{array}$ & $\begin{array}{l}\text { G-C } \\
\text { L.D. Caulk } \\
\text { Dentoria }\end{array}$ & $\begin{array}{l}\text { powder } \\
\text { powder } \\
\text { capsulated }\end{array}$ & $\begin{array}{l}\text { VR-11 } \\
060677 \\
1489\end{array}$ \\
\hline spherical & $\begin{array}{l}\text { Spherical } 6 \\
\text { Spherical } 8 \\
\text { Spherical } 10 \\
\text { Hi Atomic M } \\
\text { Atomize Fine }\end{array}$ & $\begin{array}{l}\text { Shofu } \\
\text { Shofu } \\
\text { Shofu } \\
\text { G-C } \\
\text { Toyo }\end{array}$ & $\begin{array}{l}\text { powder } \\
\text { powder } \\
\text { powder } \\
\text { powder } \\
\text { powder }\end{array}$ & $\begin{array}{l}13 \\
527 \\
33 \\
\text { DO-31 } \\
8012\end{array}$ \\
\hline $\begin{array}{l}\text { High copper } \\
\text { dispersant } \\
\text { (lathe-cut) }\end{array}$ & $\begin{array}{l}\text { Dispersalloy, powder } \\
\text { Dispersalloy, tablet } \\
\text { Amalcap non gamma-2 } \\
\text { Epoque } 80 \\
\text { DP Alloy }\end{array}$ & $\begin{array}{l}\text { Johnson \& Johnson } \\
\text { Johnson \& Johnson } \\
\text { Vivadent } \\
\text { Scania } \\
\text { Toyo }\end{array}$ & $\begin{array}{l}\text { powder } \\
\text { tablet } \\
\text { capsulated } \\
\text { powder } \\
\text { powder }\end{array}$ & $\begin{array}{l}1164-2 \\
19 \mathrm{JG} \\
60616 \\
7-090 \\
901-8013\end{array}$ \\
\hline $\begin{array}{l}\text { single composition } \\
\text { (spherical) }\end{array}$ & $\begin{array}{l}\text { Spherical D** } \\
\text { Dialloy } \\
\text { Lumi Alloy } \\
\text { Sybraloy }\end{array}$ & $\begin{array}{l}\text { Shofu } \\
\text { G-C } \\
\text { G-C } \\
\text { Kerr }\end{array}$ & $\begin{array}{l}\text { powder } \\
\text { powder } \\
\text { powder } \\
\text { capsulated }\end{array}$ & $\begin{array}{l}017608 \\
\text { JO-21 } \\
070711 \\
70912\end{array}$ \\
\hline
\end{tabular}

* fluoride containing alloy

** Indilloy

Table 2 Mixing procedure

\begin{tabular}{lclcc}
\hline \multicolumn{1}{c}{ Amalgam alloy } & Hg/alloy ratio & \multicolumn{1}{c}{ Amalgam mixer } & $\begin{array}{c}\text { Manufacturer's } \\
\text { recommended } \\
\text { mixing time } \\
\text { (sec.) }\end{array}$ & $\begin{array}{c}\text { Pestle } \\
\text { or } \\
\text { ball }\end{array}$ \\
\hline Luna 2 & 1.0 & Hi-Mix & 15 & + \\
Optaloy & 1.0 & Silamat & 11 & - \\
Fluor Alloy & 1.2 & Shofu Amalgam Mixer D & 10 & - \\
Spherical 6 & 0.82 & Shofu Amalgam Mixer D & 10 & - \\
Spherical 8 & 0.82 & Shofu Amalgam Mixer D & 10 & - \\
Spherical 10 & 0.82 & Shofu Amalgam Mixer D & 10 & - \\
Hi Atomic M & 0.75 & Hi-Mix & 8 & - \\
Atomize Fine & 0.85 & Shofu Amalgam Mixer D & 10 & - \\
Dispersalloy, powder & 1.0 & Shofu Amalgam Mixer D & 10 & + \\
Dispersalloy, tablet & 1.0 & Shofu Amalgam Mixer D & 10 & + \\
Amalcap non gamma-2 & 1.2 & Silamat & 5 & - \\
Epoque 80 & 1.2 & Silamat & 5 & - \\
DP Alloy & 0.85 & Shofu Amalgam Mixer D & 10 & - \\
Spherical D & 0.86 & Shofu Amalgam Mixer D & 10 & - \\
Dialloy & 0.82 & Hi-Mix & 10 & - \\
Lumi Alloy & 0.83 & Hi-Mix & 15 & - \\
Sybraloy & 0.9 & Silamat & 10 & - \\
\hline
\end{tabular}


Table 3 Composition of the applied amalgam alloys (manufactures' expression)

\begin{tabular}{lllll}
\hline \multirow{2}{*}{ Amalgam alloy } & \multicolumn{4}{c}{ Composition $(\%)$} \\
\cline { 2 - 3 } & $\mathrm{Ag}$ & $\mathrm{Sn}$ & $\mathrm{Cu}$ & \multicolumn{1}{c}{ others } \\
\hline Luna 2 & 70 & 25.5 & 3 & $1.5 \mathrm{Zn}$ \\
Optaloy* & 70 & 28 & 2 & (non zinc) \\
Fluor Alloy & 65.9 & 27.0 & 4.5 & $1.6 \mathrm{Zn}, 1.0 \mathrm{SnF}_{2}$ \\
Spherical 6 & 70 & 28 & & (non zinc) \\
Spherical 8 & 70 & 28 & & (non zinc) \\
Spherical 10 & 70 & 28 & & (non zinc) \\
Hi Atomic M & 70 & 27 & 3 & (non zinc) \\
Atomize Fine & 70 & 25 & & \\
Dispersalloy, powder** & 70 & 18 & 12 & (zinc) \\
Dispersalloy, tablet** & 70 & 18 & 12 & (zinc) \\
Amalcap non gamma-2 & 70.1 & 18.0 & 19 & \\
Epoque 80 & 42.0 & 29.4 & 25.0 & $0.2 \mathrm{Zn}, 1.6 \mathrm{Hg}$ \\
DP Alloy & 70 & 25 & & \\
Spherical D & 60 & 22 & 13 & 5 In \\
Dialloy & 60 & 25 & 10 & 1 Pd \\
Lumi Alooy & 56 & 29 & 15 & (non zinc) \\
Sybraloy & 40 & 30 & 30 &
\end{tabular}

* Nomoto, S. (1980)

** Ogura, H. (1981)

Composition of the alloy is listed in Table 3.

\section{RESULTS}

Compressive strength is shown in Figs. 1 to 4.

Figure 1 shows the strength of conventional low copper lathe-cut amalgams. Although slightly low strength was observed with fluoride incorporated amalgam during 1-24 hour, comparable strength was obtained after 7 to 30 days in those without fluoride. Thus, incorporation of fluoride influences only the strength of amalgam at initial stage of hardening. Generally, the strength of conventional lathe-cut amalgam increased over a long period of time.

With conventional low copper spherical amalgam (Fig. 2), a moderate increase in strength similar to that of the lathe-cut amalgam was observed, although the 24 hourstrength was fairly high.

In regard to the high copper amalgams (Figs. 3 and 4), the strength of amalgam during 1-7 and 24 hour was considerably higher than those of conventional amalgams. However, differences in the increase in strength were seen between the dispersant (Fig. 3) and the single compositional (Fig. 4) amalgams. The increase in strength up to 24 hours was moderately in case of dispersant type. On contrary, a remarkable increase was observed within a limited time with the single compositional high copper type. 


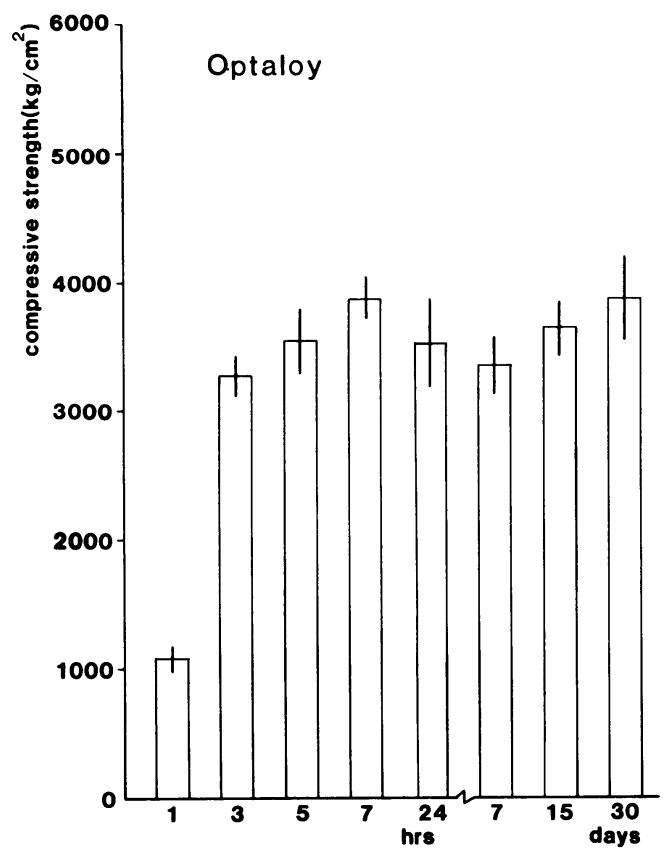

(1)

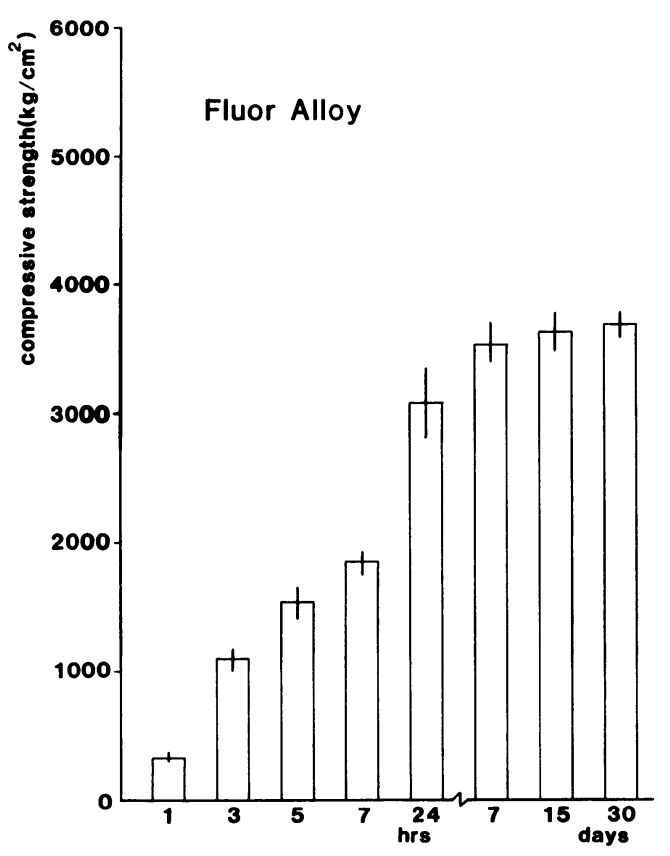

(3)

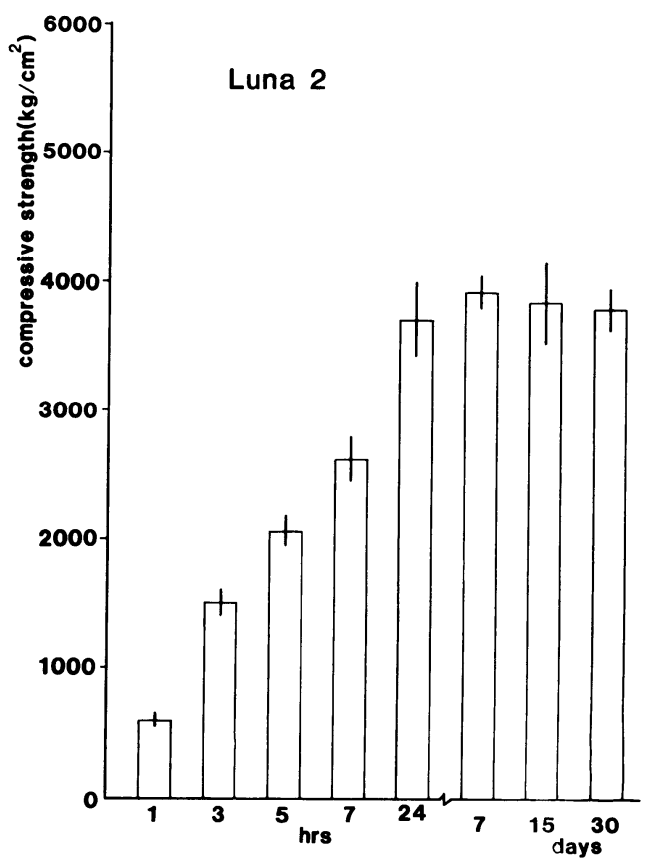

(2)

Figure 1 (1)-(3) Change in compressive strength of low copper lathe-cut amalgams 


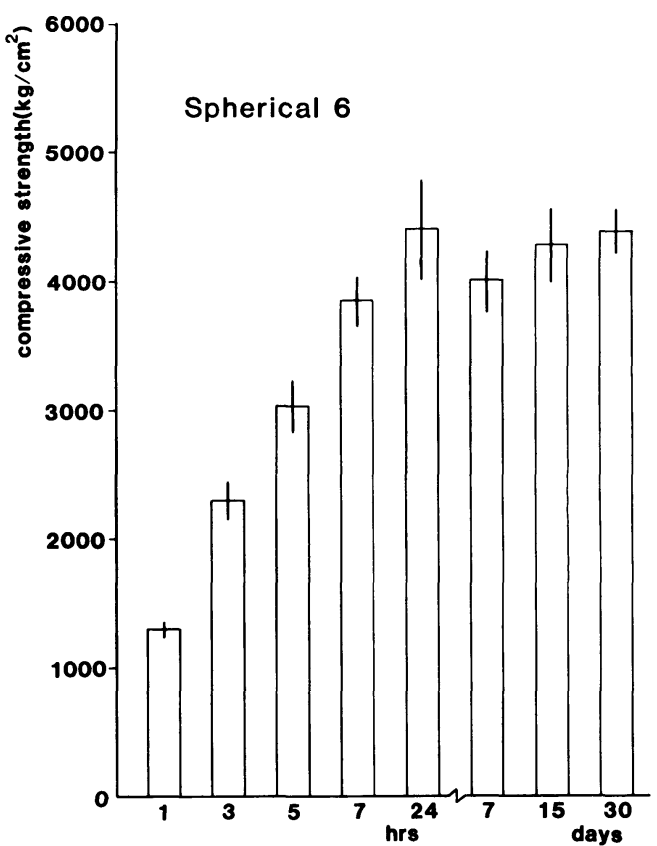

(1)

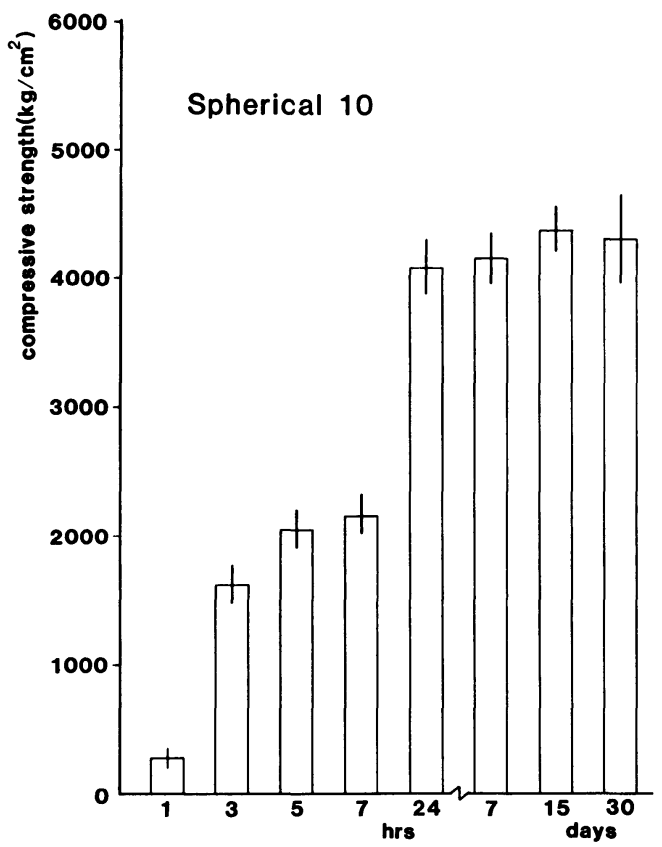

(3)

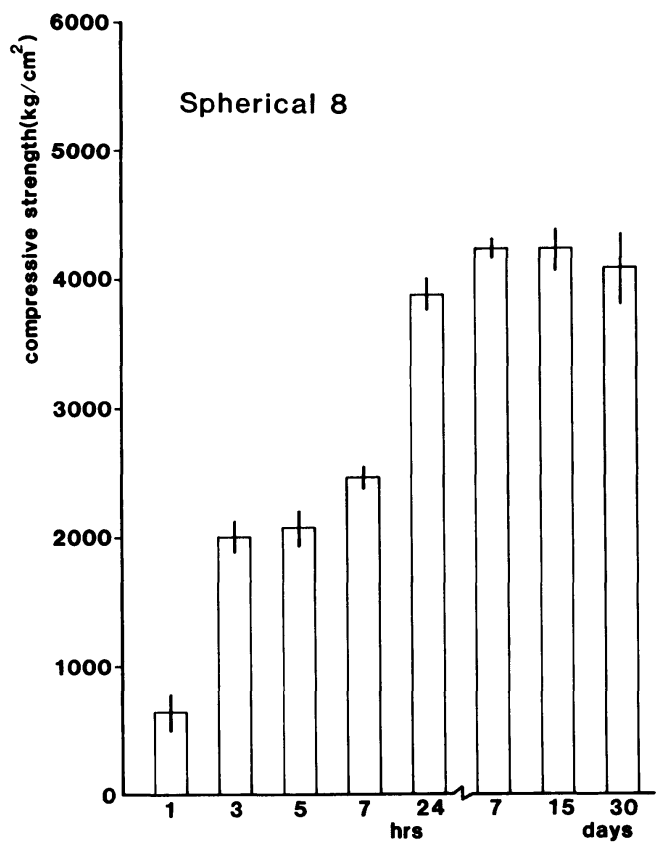

(2)

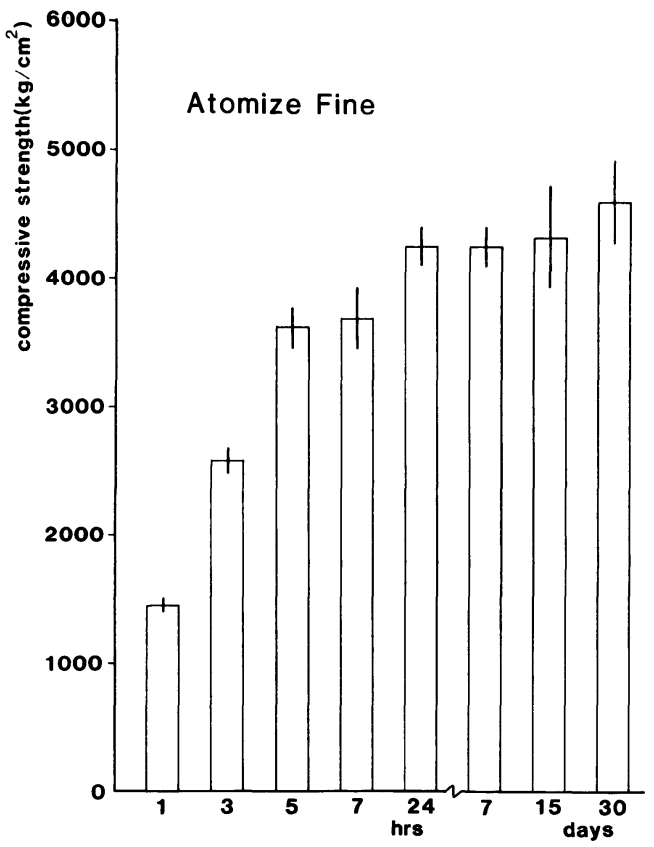

(4) 


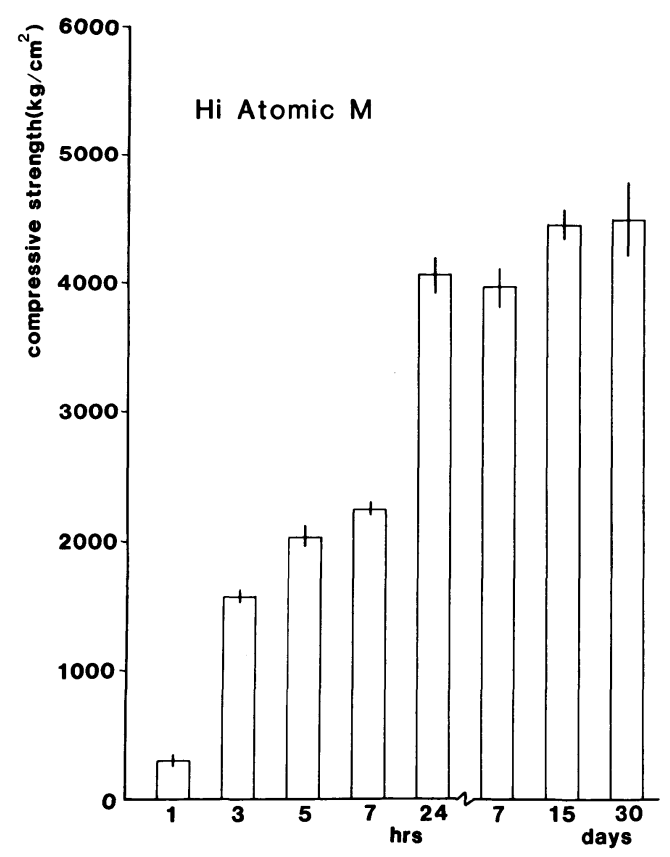

Figure 2 (1)-(5) Change in compressive strength of low copper spherical amalgams

(5)

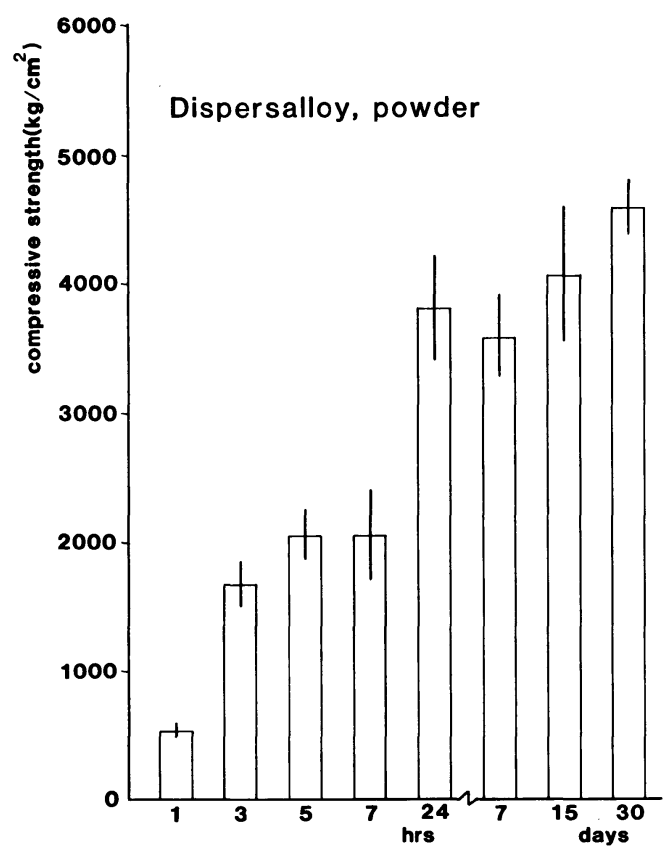

(1)

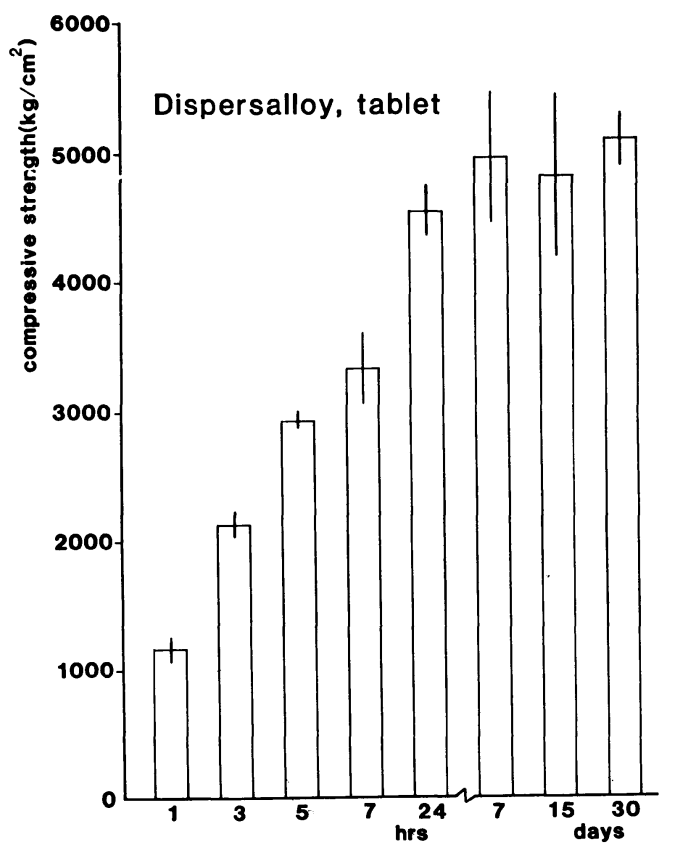

(2) 


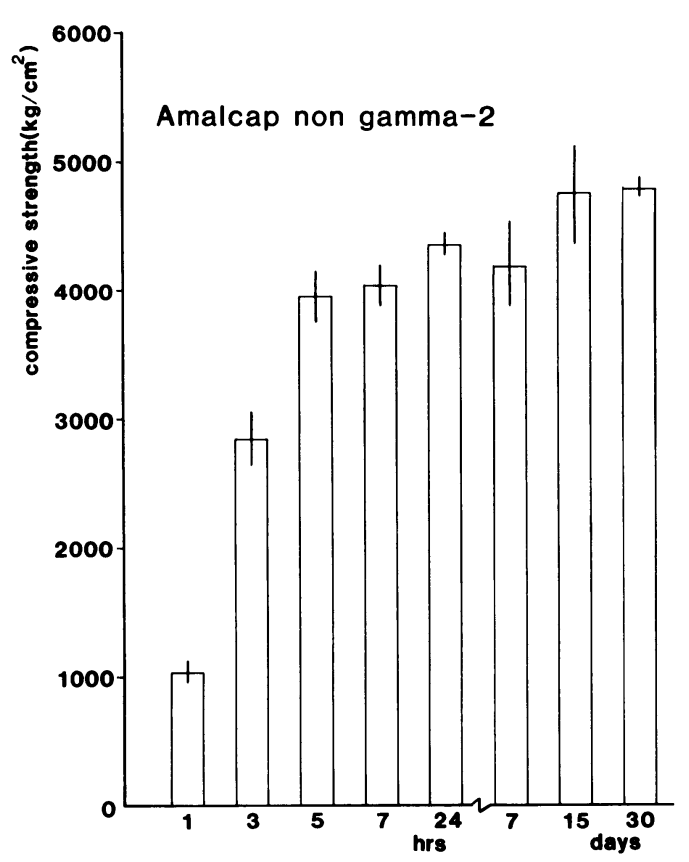

(3)

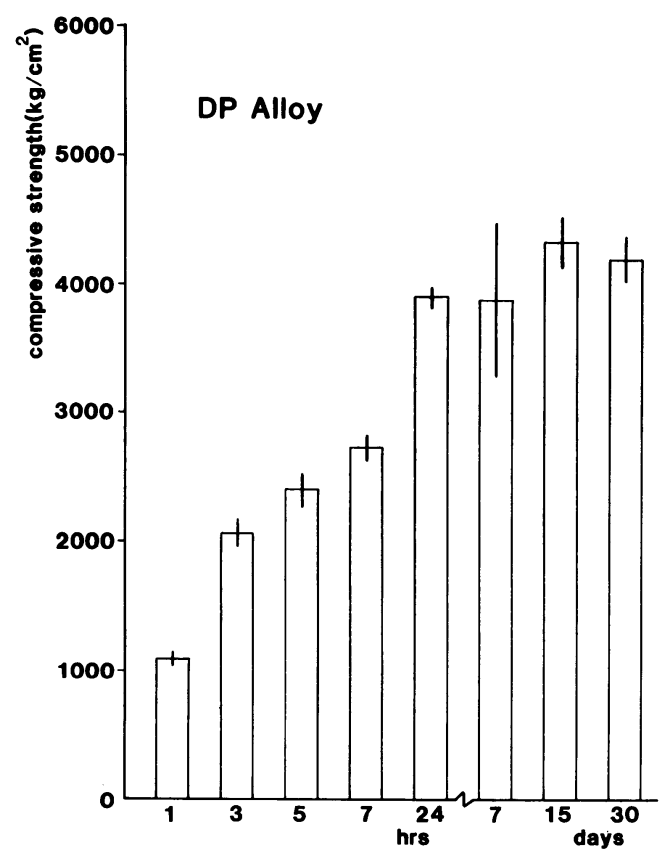

(5)

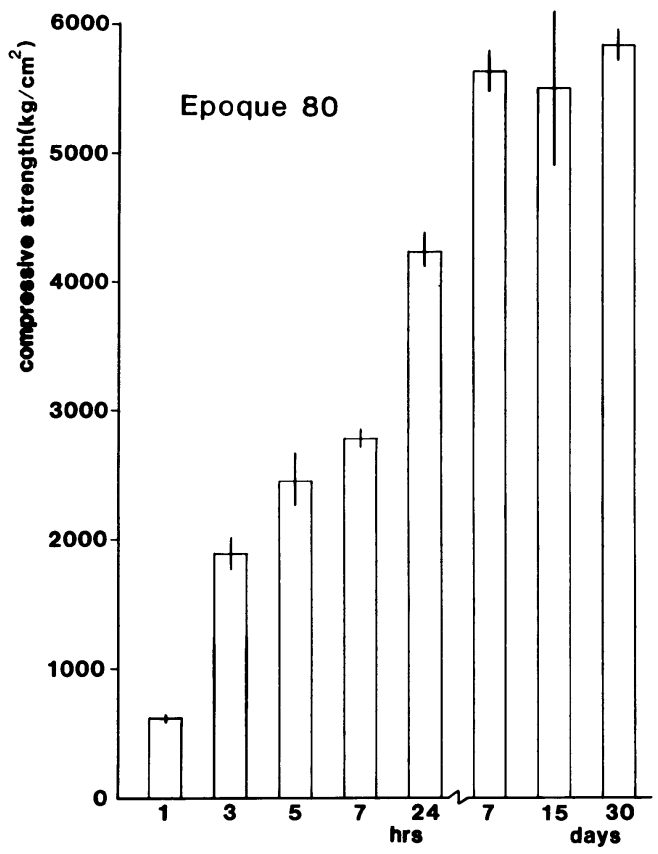

(4)

Figrue $3(1)-(5)$ Change in compressive strength of dispersant type high copper amalgams 


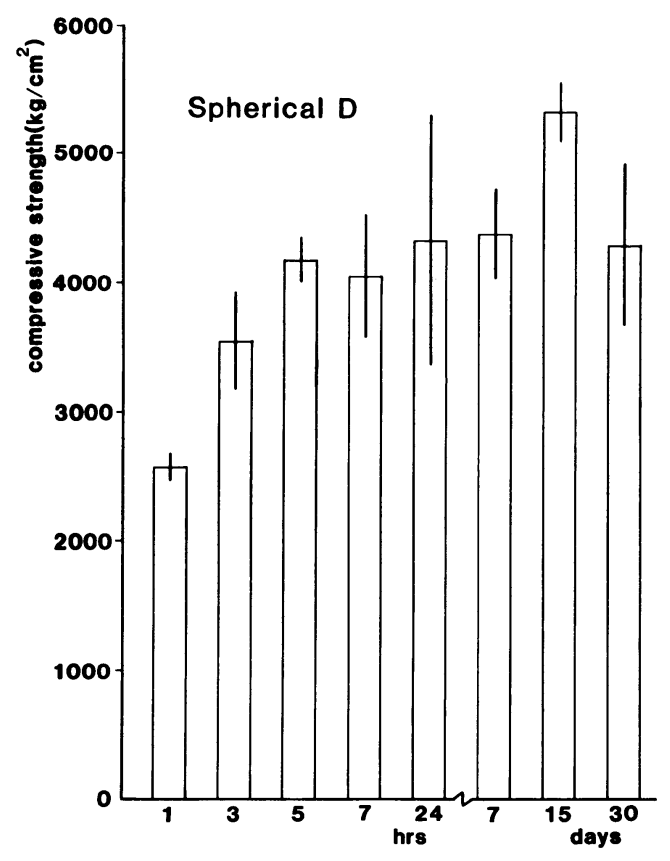

(1)

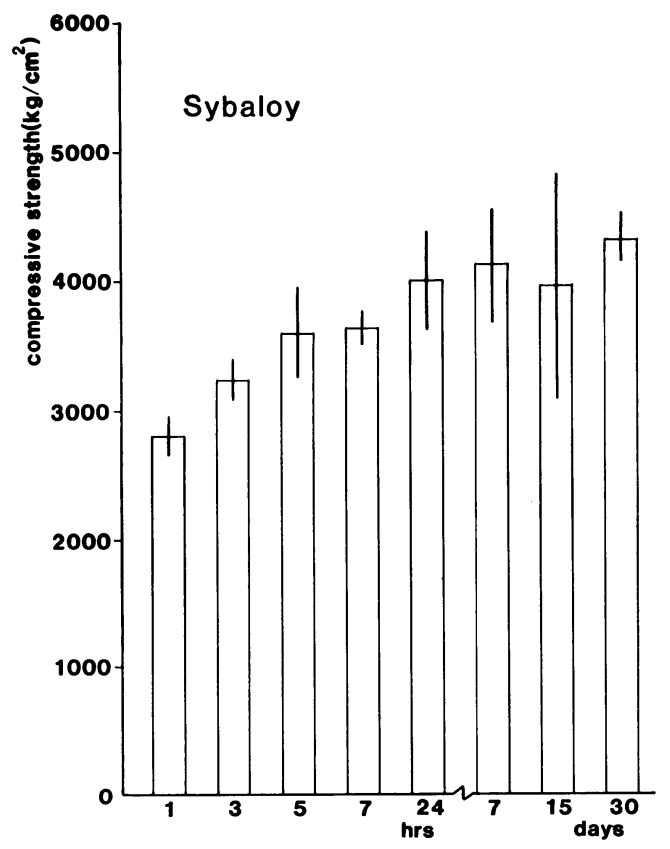

(3)

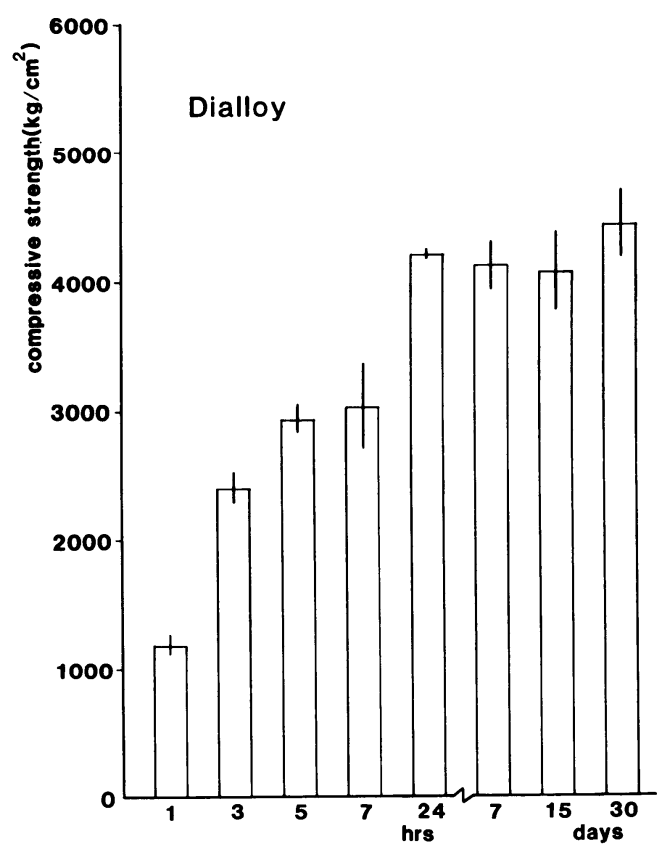

(2)

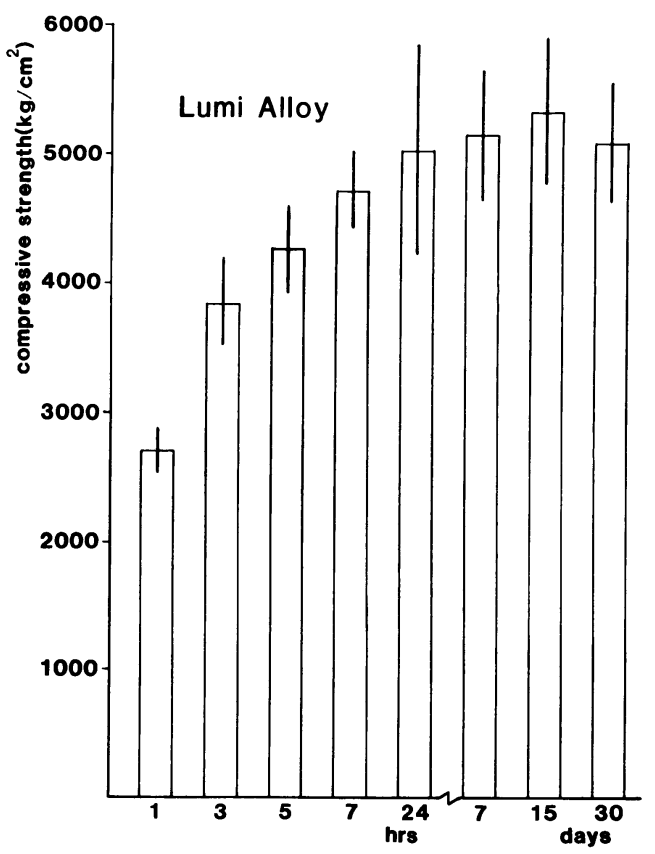

(4)

Figure 4 (1)-(4) Change in compressive strength of single compositional type high copper amalgams 


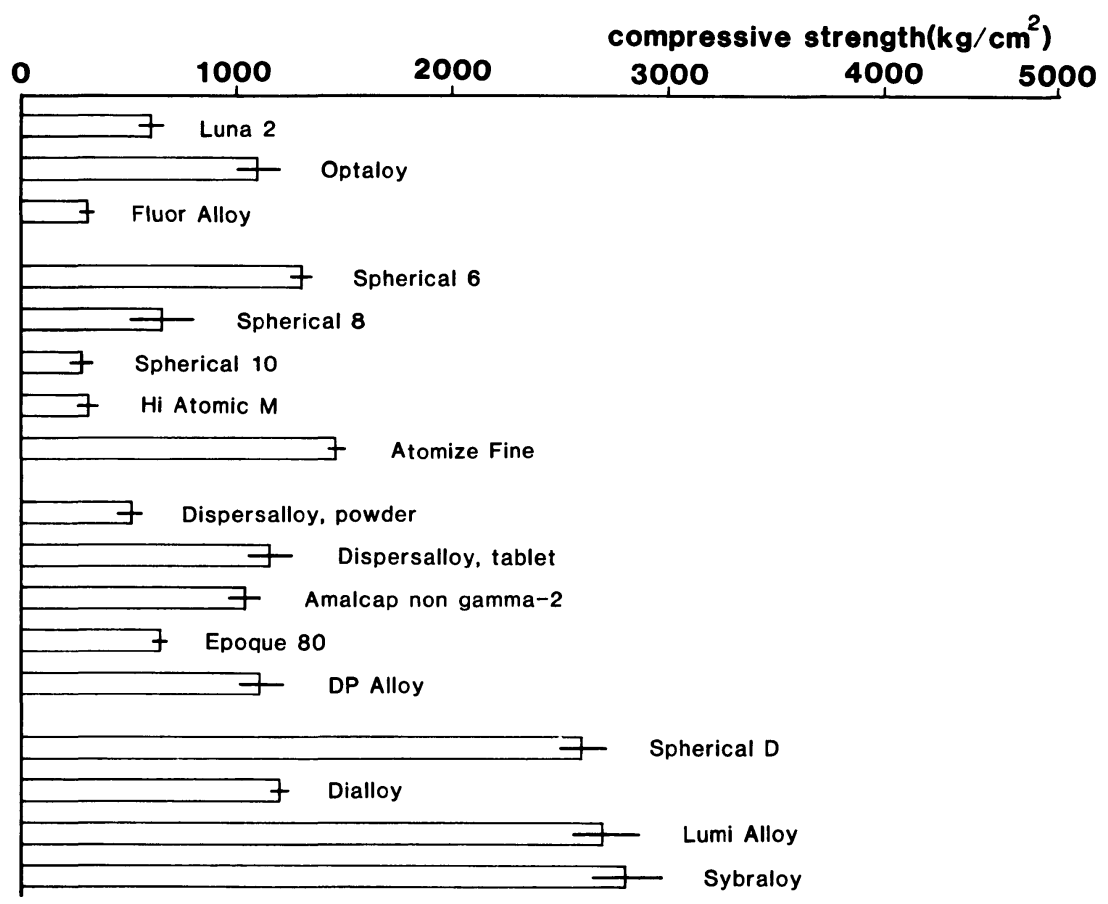

Figure 51 hour-compressive strength

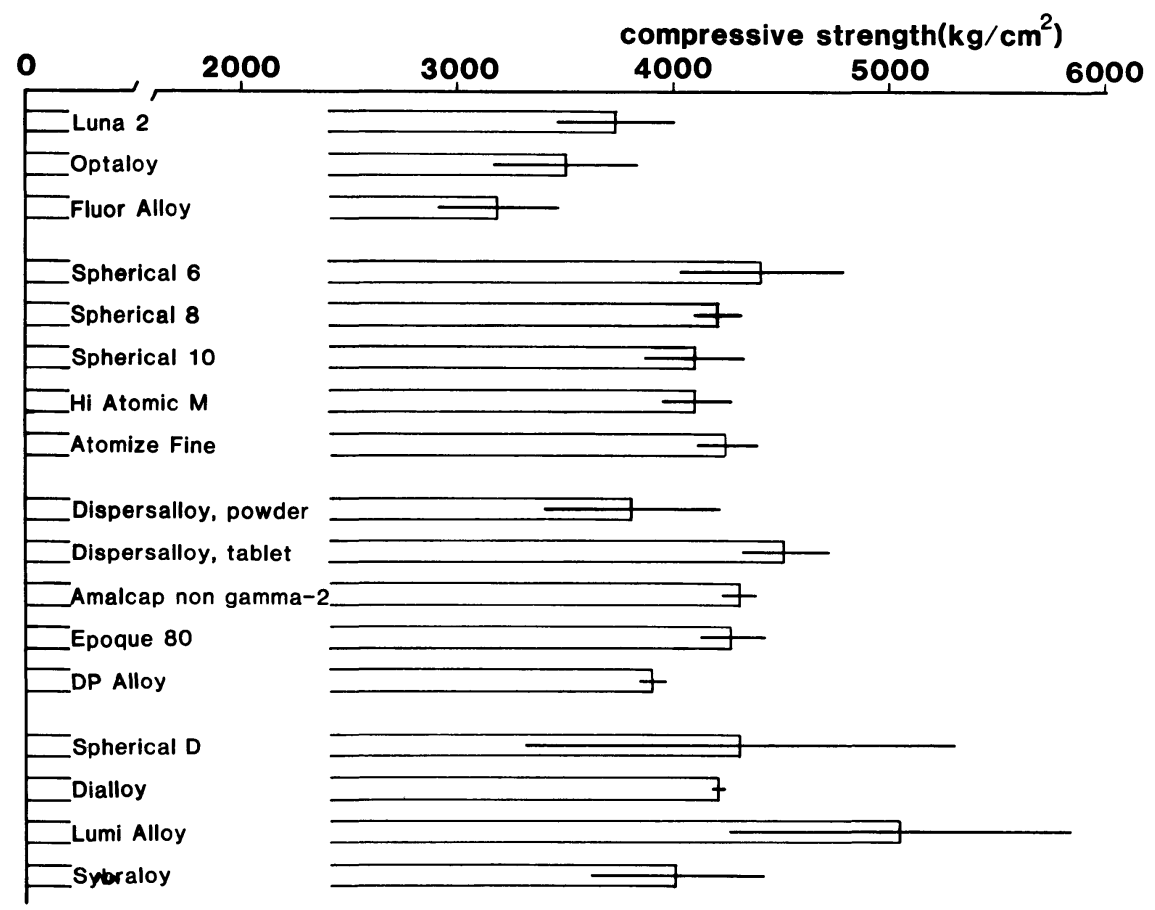

Figure 624 hour-compressive strength 


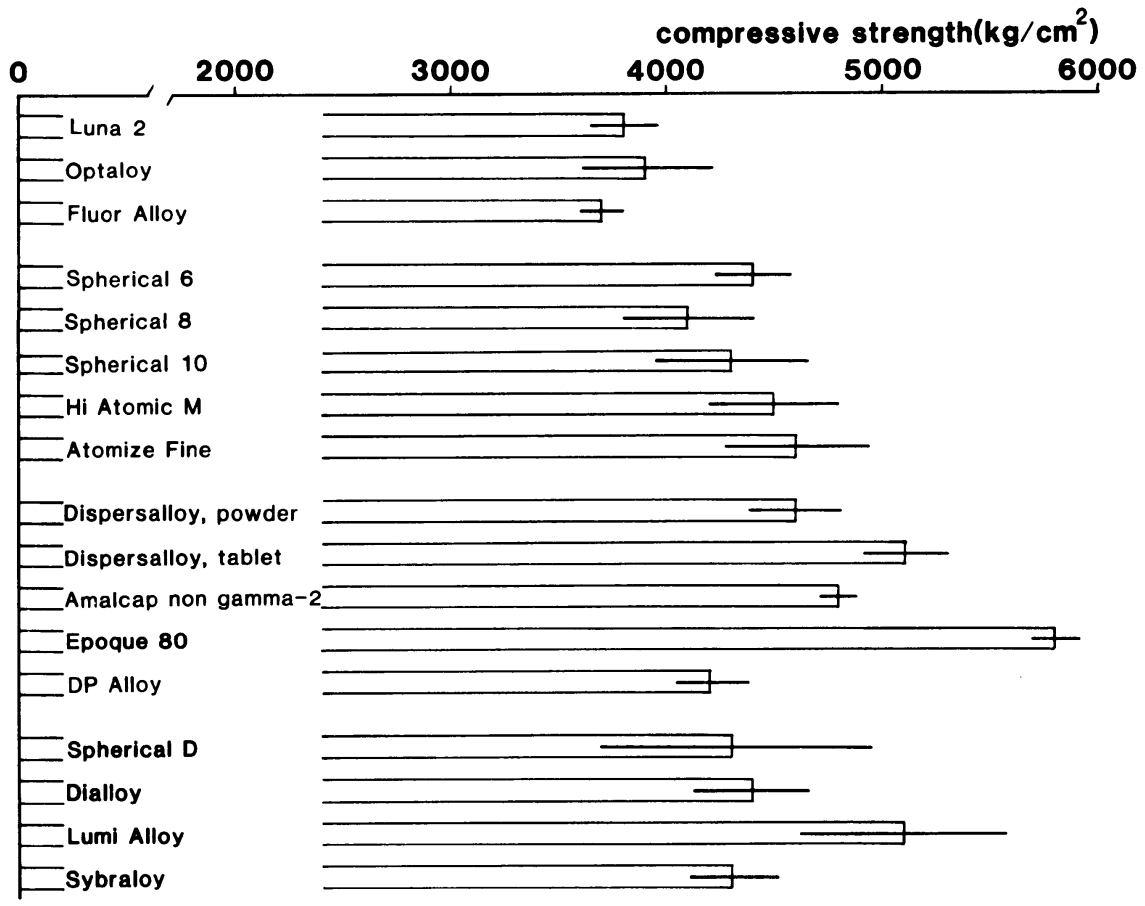

Fig. 730 day-compressive strength

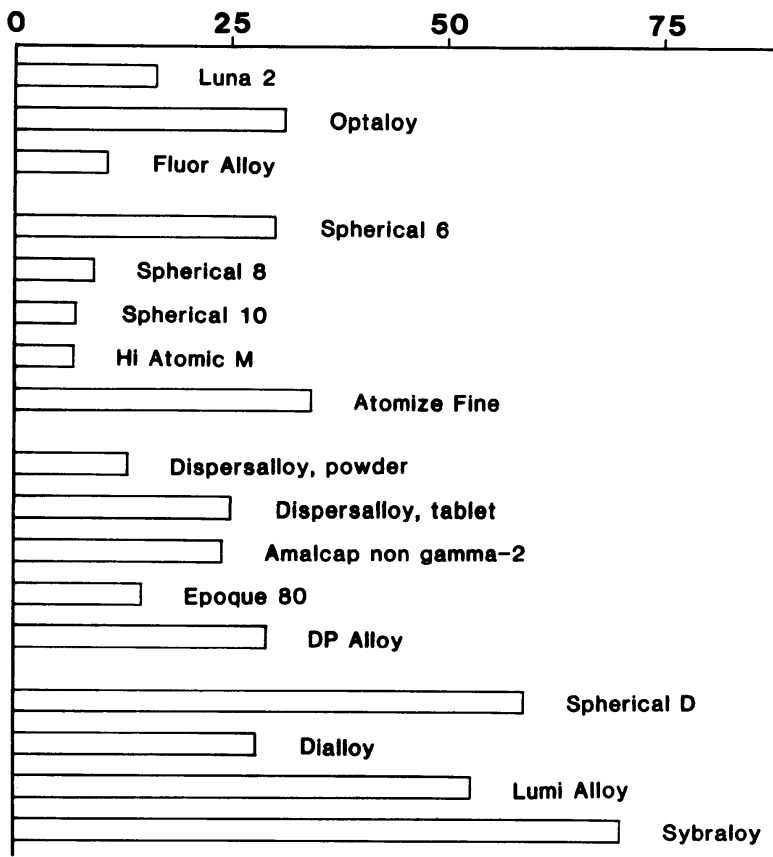

(\%)

Figure 8 Percentage of 1 hour to 24 hour compressive strength 


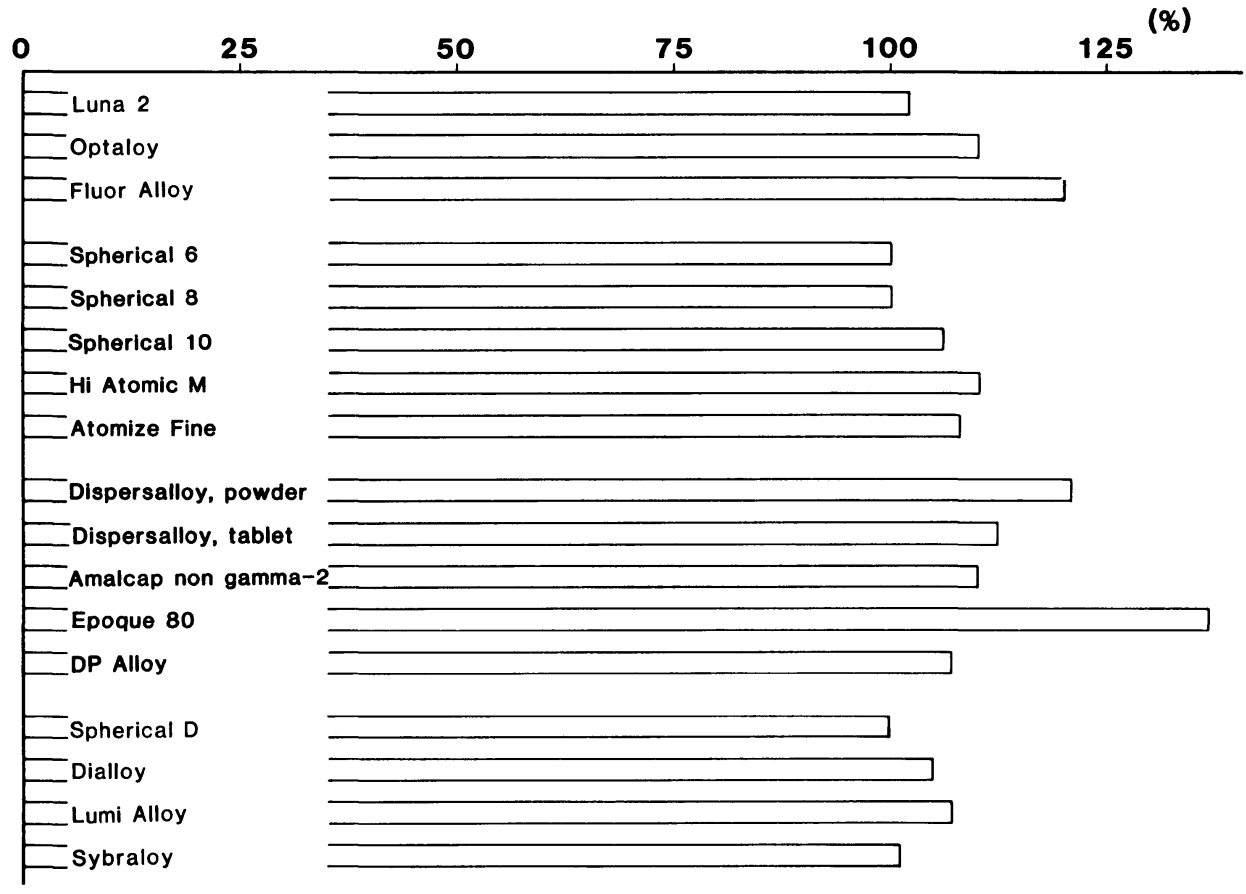

Figure 9 Percentage of 30 day to 24-hour compressive strength

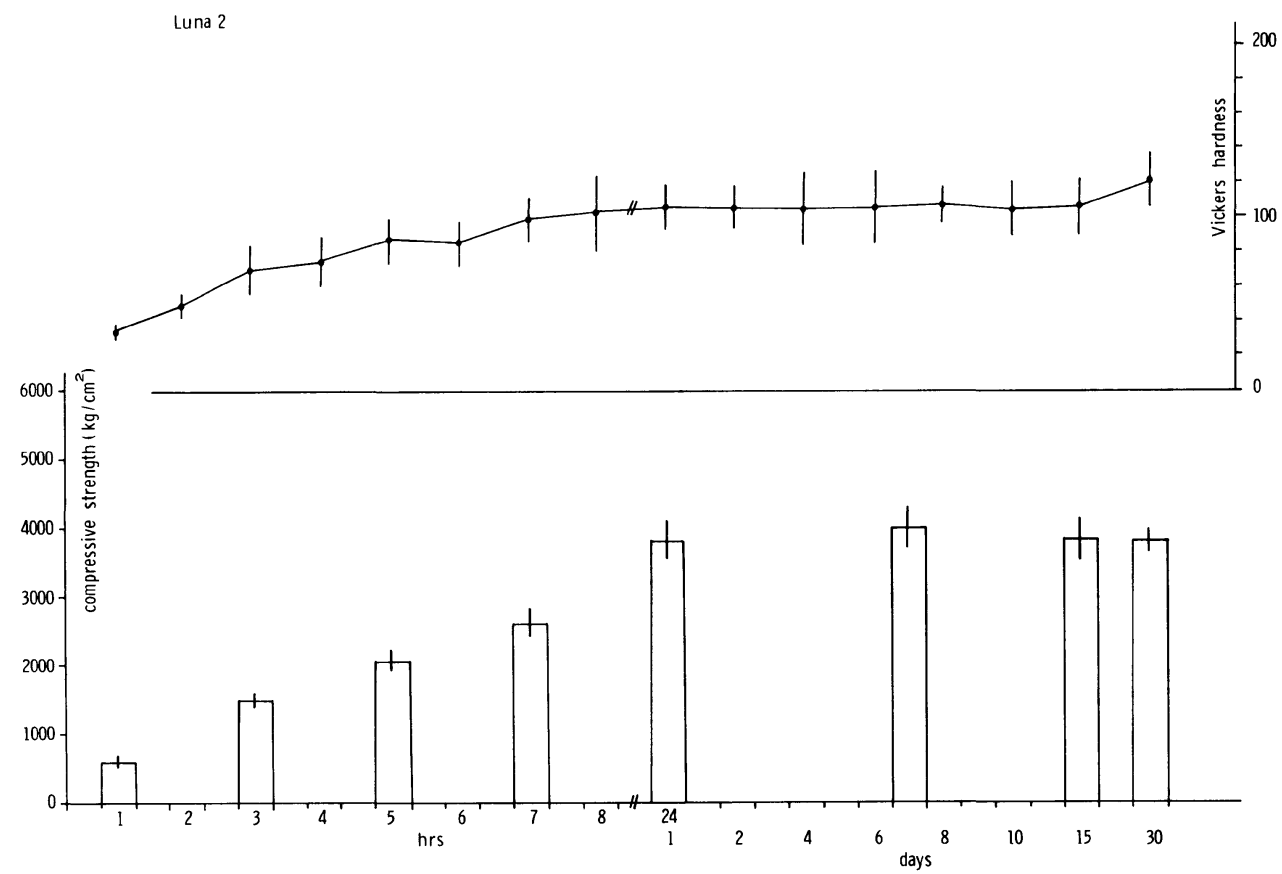

Figure 10 Change in compressive strength and hardness of a low copper lathe-cut amalgam 
Spherical 8

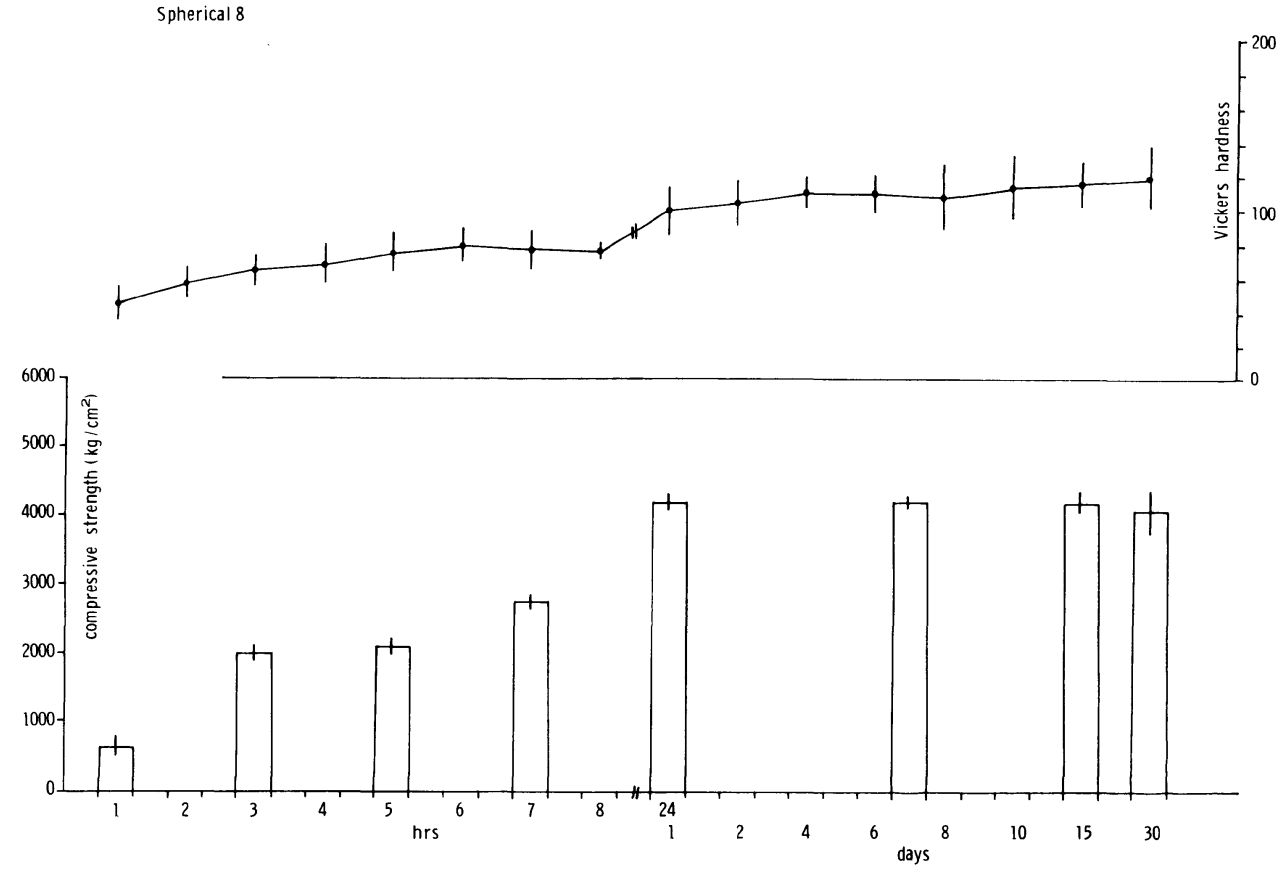

Figure 11 Change in compressive strength and hardness of a low copper spherical amalgam

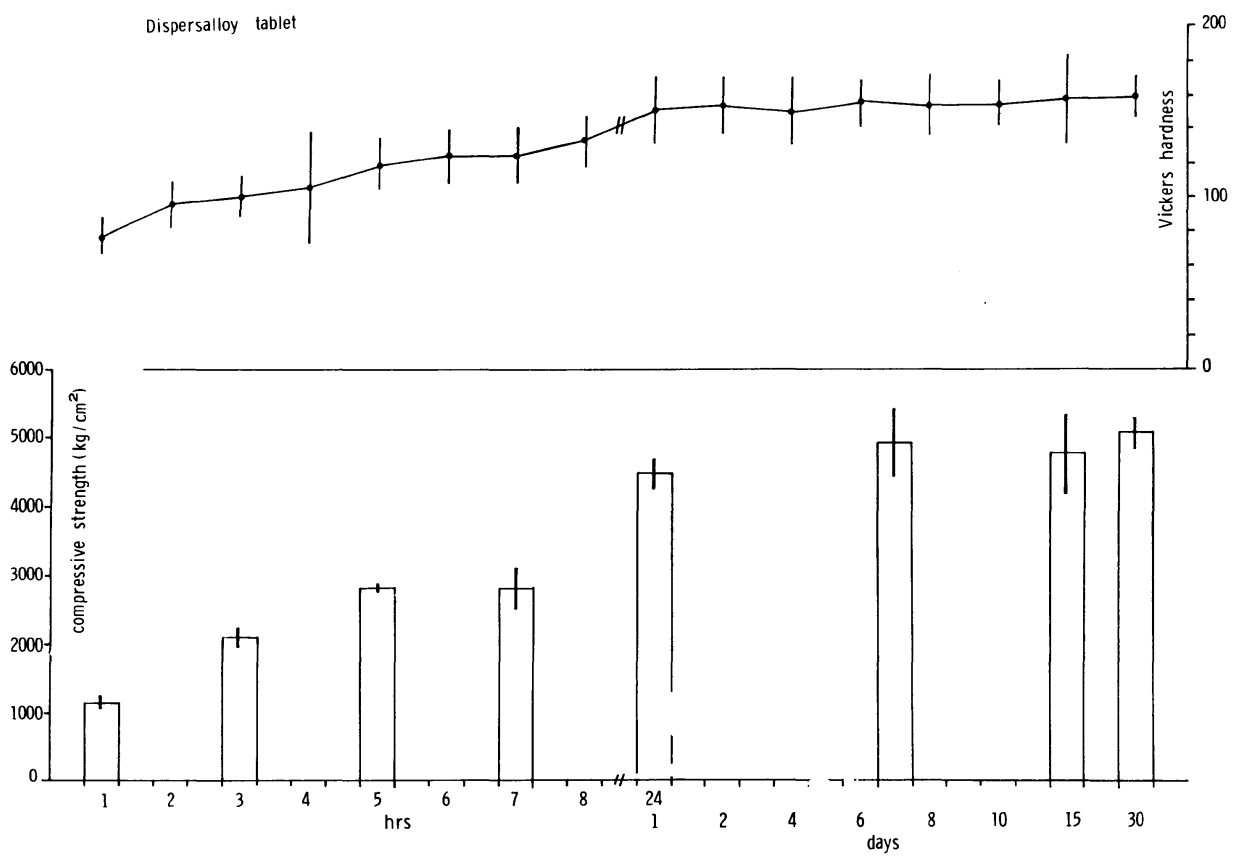

Figure 12 Change in compressive strength and hardness of a dispersant (lathe-cut) type amalgam 


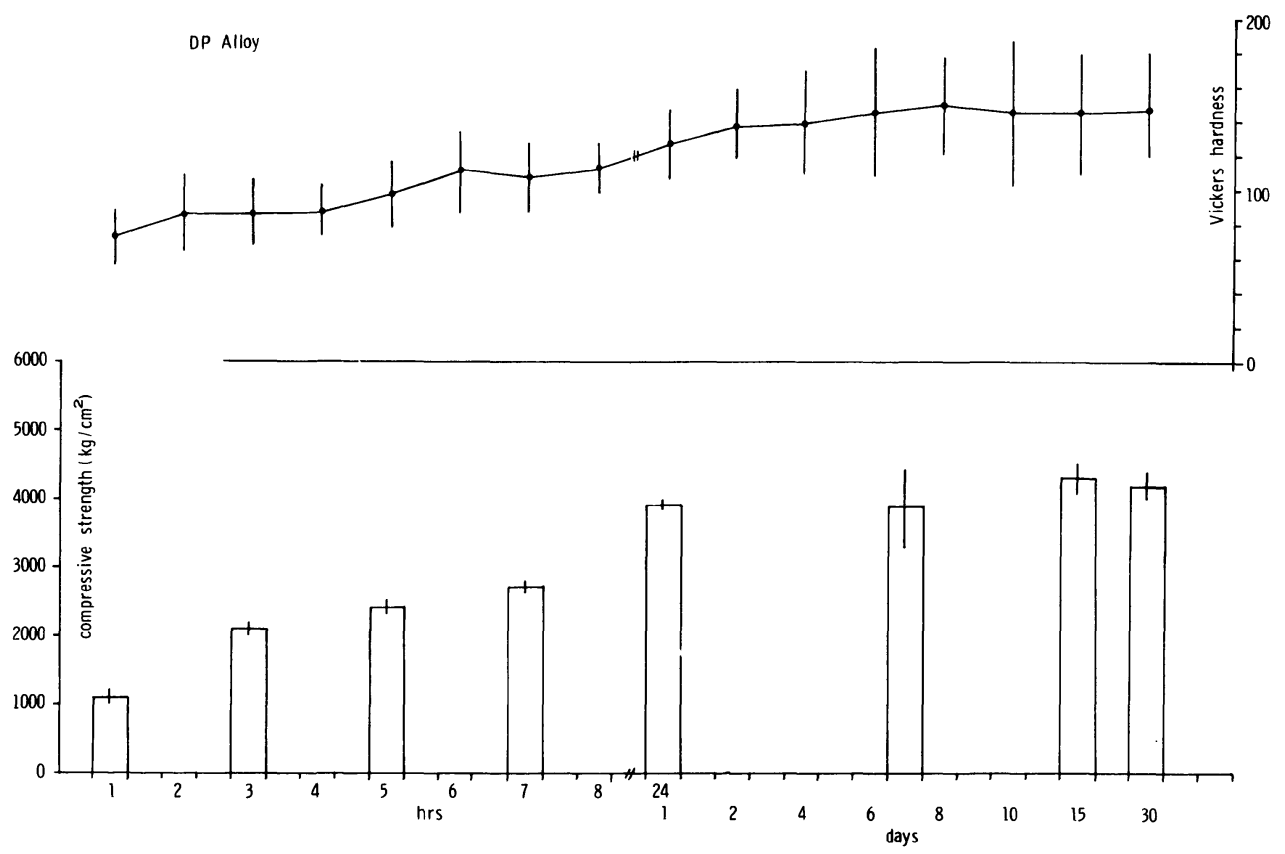

Figure 13 Change in compressive strength and hardness of a dispersant (spherical) type high copper amalgam

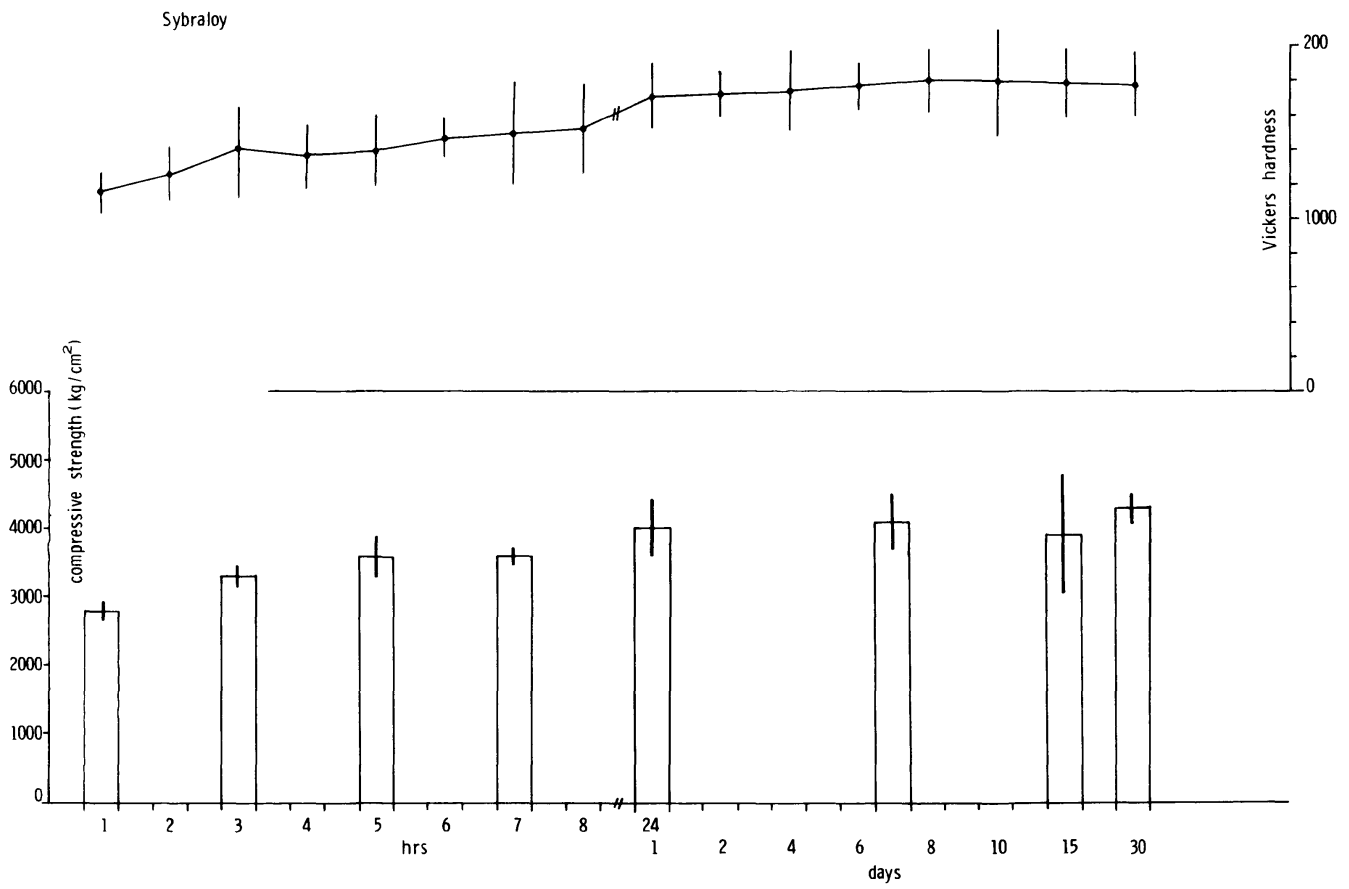

Figure 14 Change in compressive strength and hardness of a single compositional type high copper amalgam 
The 1 hour, 24 hour and 30 day strength of each amalgam was exhibited in Figs. 5 to 7. There appears to be two obvious difference, i.e., slow or rapid, in regard to the hardening of amalgam. The percentage of 1 hour to 24 hours and 30 day to 24 hour-strength was shown in Fig. 8 and 9, respectively. Single compositional high copper amalgams show a high percentage on 1 hour to 24 hour strength and low percentage on 30 day to 24 hour strength, in contrast to those of lathe-cut type dispersant high copper amalgams. Thus, the hardening of the single compositional high copper amalgam occurs and terminates within a considerably limited time than others.

The relationship between strength and previously reported ${ }^{4)}$ hardness of 5 representative alloys are shown in Figs. 10 to 14 . Although their relationship was apparent, the increase in hardness was greater than that of strength in case of single compositional high copper amalgams.

\section{DISCUSSION}

The increase in compressive strength on standing has been applied as an index for the hardening of dental amalgam ${ }^{7,8}$. There are two factors which influence the strength of dental amalgam. One is the alloy itself, i.e., composition, heat treatment, particle size, shape and its distribution. Second is operative factor, i.e., mixing with mercury and condensation to the prepared cavity.

Regarding commercially available alloys, those having considerable strength even in the initial stage of hardening, have become widely used in this country ${ }^{1)}$, because these rapid hardening alloys have advantages, such as, resistance to the occlusal stress even at the initial stage of hardening, time saving for the carving and removing the matrix band in the case of Class II restoration. However, it is also reported ${ }^{8,9)}$ that the porosity and residual mercury content is increased at the marginal region of the restoration, due to the insufficient condensation because the manipulative time of these alloys were generally short. At present, there is little information on the relationship between the clinical results and the increase in compressive strength on standing, in regard to the commercially available alloys.

It has been shown ${ }^{10,11)}$, that the smaller the alloy particle, the greater the strength of resultant amalgam during hardening. However, few reports have been published in relation to its copper content. In this study, only single compositional high copper amalgams exhibited a very large initial strength. In dispersant type high copper alloys, although their copper content were similar, such a large initial strength was never obtained regardless of their particle shape, i.e., either lathe-cut or spherical. Thus it was considered that no correlation existed between copper content and initial strength. For example, strength increased more slowly with Epoque 80 than Spherical D, although copper content of the former is much greater than the latter.

In case of conventional low copper amalgam, slightly large strength was obtained at spherical particle alloy than lathe-cut one, although their difference was not so marked. However, Dispersalloy tablet and Amalcap non gamma-2 showed more rapid increase in strength than DP Alloy, although the particles were lathe-cut in former and spherical in latter. In addition, pairs of both Dispersalloy powder and tablet, Dialloy and Lumi 
Alloy were produced by the same manufacturer and had the same particle shape, yet, showed a distinctive difference in respect to their increase in strength.

Recent investigation ${ }^{12)}$, showed that the difference in the hardening between dispersant and single compositional high copper alloy was not simply due to particle shape, but due to microstructure during hardening. Namely, in single compositional high copper alloy, $\eta^{\prime}\left(\mathrm{Cu}_{6} \mathrm{Sn}_{5}\right)$ phase was formed on the particle surface of alloy even at the initial stage of hardening. In addition to the formed $\eta^{\prime}$ phase has excellent mechanical properties ${ }^{13)}$, it penetrate into the alloy particle making an wedge. This strengthning mechanism was considered to have an important role on the large initial strength. However, among the single compositional high copper alloys, one alloy (Dialloy) showed initial strength similar to that of dispersant high copper one. Thus, it is impossible to explain the rapid increase in compressive strength during hardening of single compositional high copper alloy, based on its particle shape alone. The heat treatment of alloy may affect the hardening of amalgam with other factors, such as, composition and particle shape.

Results obtained in this study favourably agreed with those reported previously ${ }^{4}$, except for single compositional high copper amalgams. Namely, unlike hardness, strength of single compositional high copper amalgam was not always greater than that of either dispersant type high copper or conventional low copper spherical ones. Thus, single compositional high copper amalgam appeared to harder and more brittle than others.

Although the name is identical as "high copper alloy", the dispersant type and single compositional ones have definitely different hardening behaviour. Further investigations are needed on the relationship between strength or hardness during hardening and clinical performance of resultant restorations.

\section{CONCLUSIONS}

Compressive strength of 17 commercially available low and high copper amalgams was determined periodically from 1 hour to 30 days after mixing with mercury. Following results were obtained:

1. Large initial strength followed by a rapid increase was observed with single compositional high copper amalgams. This was not observed with dispersant type high copper amalgams although their copper content was similar.

2. On the other hand, with low copper amalgams, a slightly large initial strength and its moderate increase was observed during hardening of spherical particle amalgams, in comparison with lathe-cut ones.

3. Comparing the 30 day-strength to that of 24 hour, dispersant type high copper amalgam exhibited the greatest increase followed by conventional low copper lathe-cut, conventional low copper spherical, and the single compositional high copper amalgam showed the least among all. Thus, single compositional high copper amalgam appeared to harden in a considerably limited time.

4. The difference in strength during hardening was considered not only due to composition and particle shape of an alloy, but also due to surface characteristics followed by its heat treatment. 
5. Although the name is similar to "high copper alloy", the hardenings of both dispersant and single compositional type alloy are considerably different.

\section{REFERENCES}

1) Nakai, H.: Characteristics of commercially available amalgam alloys, Nippon Dent. Review, 478: 97-114, 1982 (in Japanese)

2) Eames, W.B. and MacNamara, F.J.: Eight high copper amalgam alloys and six conventional alloys compared, Oper. Dentistry, 1: 98-107, 1976.

3) Duke, E.S., Cochran, M.A., Moore, B.K. and Clark, H.E.: Laboratory profiles of 30 high copper amalgam alloys, J. Amer. Dent. Ass., 105: 636-640, 1982.

4) Nakai, H., Irie, M. and Hashimoto, H.: Change in the hardness of dental amalgams in relation to time, Dent. Mater. J., 2: 18-29, 1983.

5) Council on Dental Materials and Devices: Revised American Dental Association Specification No. 1 for alloy for dental amalgam, J. Amer. Dent. Ass., 95: 614-617, 1977.

6) Council on Dental Materials, Instruments, and Equipment: Addendum to American National Standard Institute/American Dental Association Specification No. 1 for alloy for dental amalgam, J. Amer. Dent. Ass., 100: 246, 1980.

7) Phillips, R.W.: Compressive strength of amalgam as related to time, J. Dent. Res., 28: 348-355, 1949.

8) Rhodes, B.F., Swartz, M.L. and Phillips, R.W.: Physical properties of two high copper amalgams and a conventional amalgam, Oper. Dentistry, 4: 71-74, 1979.

9) Espevik, S.: One hour compressive strength of dental amalgam, Scand. J. Dent. Res., 83: 37-40, 1975.

10) Nagai, K., Ohashi, M. and Miyazu, H.: Studies on spherical amalgam alloy in the light of dental technology, J. Nihon Univ. Dent. Sch., 8: 149-185, 1966.

11) Craig, R.G. and Peyton, F.A.: Restorative dental materials, 5th ed., C.V. Mosby Co., 1975, pp. 185-186.

12) Okabe, T., Mitchell, R., Butts, M.B. and Fairhurst, C.W.: A study of high copper amalgams III. SEM observations of amalgamation of high copper powders, J. Dent. Res., 57: 975-982, 1978.

13) Takatsu, T., Iwaku, M. and Fusayama, T.: Structure and effects of non-gamma-2 amalgam, $J$. Dent. Res., 56: 40-45, 1977. 
各種歯科用アマルガムの压縮強さの経時的変化

中井宏之, 鈴木一臣, 入江正郎, 新井浩一*, 橋本弘一*

㧫山大学茵学部茵科理工学講座

*城西菌科大学曾科材料学講座

各種隶科用アマルガムアロイの便化特性を压縮強さの 経時的測定により考察した。A. D. A. 規格 No. 1 の方式 によって作製された武片について測定をおこなったとと ろ, 強さの経時的な增加の㑯向は, アロイの組成や粓状 によって特幑のあるととが分かった。即ち, 粒状からい えば, 球状アロイが, 組成からいえば高銅型アロイが, それぞれ削片状厂ロイ, 徉来型アロイに比べてより短時 間内に強さが大きくなり最大值に達した。高銅型アロイ
のうちであ単一組成型は強さの発現が短時間内に起とる あのが多く, 他のアロイに比べて 1 時間強さが特に大き くなったが，30日強さは必ずしも大きくはなく，硬化が より短時間内と進行し終了するあのであるととがわかっ た。前に報告した硬さの経時的変化と比較してみると， 単一組成型高銅アロイの強さの増加は硬さの増加に比ぺ てゆるやかで，硬く胣い材料であるととが明らかとなっ た。

In と $\mathrm{Fe}$ を含む陶材焼付用金合金の酸化層の構造

大野弘機, 神澤康夫, 川島 功

東日本学園大学歯学部米科理工学教室

In と $\mathrm{Fe}$ を総量 $1.5 \mathrm{wt} \%$ 潦刀した陶材焼付用金合金 (85.5 wt\% Au) を $1000^{\circ} \mathrm{C}, 1 \mathrm{hr}$, 大気中で酸化させ, 单金属成分の添加量を変えた場合の酸化層の構造变化を $\mathrm{X}$ 線マイクロアナライザー, $\mathrm{X}$ 線回折, 反射電子回折で 解明した。その結果，Inを $0.15 \sim 1.5$ wt \% 含む合金 (1. 35 0 wt \% Fe) では, 一様な膜厚の外部酸化層が北 成されず，合金マトリックスが部分的に露出していると
とが明らかになった。 $\mathrm{In}_{2} \mathrm{O}_{3}, \mathrm{Fe}_{2} \mathrm{O}_{3}$, 未知の鉄酸化物の 3 つの酸化物が混合した状態で合金内部に析出した。そ の形態は，合金表面では針状に，また，合金内部では塊 状に結晶粒界に析出した。この合金の内部酸化は, これ らの析出した酸化物中を酸素イオンが拡散し, 移動する ことによって進行すると考えられた。

機能性モノマーの䨑科的応用（その 8 ）

\section{Alkylene glycol monomethacrylate の酸処理 \\ エナメル質括よびデンチン質への接着性 \\ 福島忠男, 川口 稔, 井上勇介, 宮崎光治, 堀部 隆 福岡歯科大学歯科理工学教室}

充填用レジンの歯質への接着性を改善するために， diluent として側鎖長の異なる Alkylene glycol monomethacrylate を 6 種合成し，2HEMA を加えたこれら モノマーの構造と物性の関係については前報で述べた。 本報では萰質への接着性と構造との関係をさらに検討し た。すなわち, リン酸で 1 分間処理した牛甬エナメル質 とリン酸, クエン酸および EDTA で 1 分間それぞれ処 理した牛蒾デンチン質へ， 7 種のモノマーから調製した Bonding agent を薄く塗布し，その上から即重レジンを
填入して作製した接着試料について, 室温に 3 時間放置 後, 水中浸漬30日後および Thermal cycling 後に引張 り試験を行って接着力を求めた。その結果，側鎖長の短 いあのが総体的にいずれあ接着性は優れていたが, 水中 浸漬後と Thermal cycling 処理後での接着力の低下は 4HBMA, 5HPeMA および 6HHeMA が小さく, 長期間 過酷な口腔内での使用にはてれらモノマーが diluent と して有効であると考えられる。 